\title{
【書評】
}

\section{『伊坪徳宏・稲葉 敦 編著： ライフサイクル環境影響評価手法』}

\author{
(侏) 萑原製作所 岡 崎 春 雄
}

LCA は 1993 年に ISO/TC 207 でその規格化が決定されて以来, 日本において屯急速に関心 の高まりをみせた。しかし, 先行する欧米に追いっくためだけでなく, 日本で真にLCA を活 用していくためには, 日本のインベントリデータの蓄積上日本に適合した影響評価手法の開発 が不可欠であった。LCA 日本フォーラムの提言を受けて $1998 \sim 2003$ 年の 5 年間で実施され た LCA プロジェクト（正式名：製品等ライフサイクル環境影響評価技術開発）はまさにその

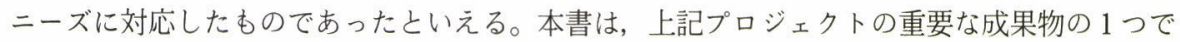
ある日本版被害算定型影響評価手法 (LIME) の手法論と利用方法についての解説書である。

LCA はライフサイクル評価を特徵とする環境側面評価手法であり，その実施手順は「目的 之調査範囲設定」一「インベントリ分析」一「影響評価」一「結果の解釈」の 4 段階で構成さ れている。本書のタイトルである「ライフサイクル環境影響評価手法」(LCIA) は, 本来

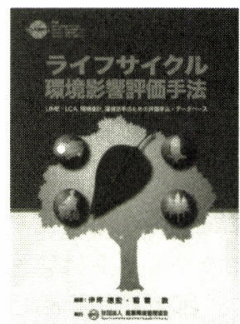
LCA の中核をなすべきこの第 3 段階「影響評価」を示す名称である。しかし，一方でこの手法分野はこれまで欧米 の主導で研究が進められ，なおかつ未だ発展途上段階でもあるため，国内にあってはLCA 実施者においてさえ十分 に習熟・理解されているとは言い難かった。LIME の開発者であある著者らはかかる状況を考慮し, 読者の理解に資 するために本書の構成に様々な工夫を施している。すなわち, 本書は LIME の内容解説にあたって, 物質比較型, 問題比較型, 被害算定型等, LCIA の最新の研究動向と対比させた記述に努め, さらに ISO-LCA 規格や環境経済学 等, 環境側面評価に関わる様々な科学分野の紹介も随所で行っている。その結果, 本書は単なる LIMEの解説書に とどまらず,メインタイトル通り LCIA 手法全体に対する総合理解をあ提供し得る体裁となっている。

本書は全 4 章で構成されており，第 1 章ではまず LCIA 研究の歴史と国際動向を整理・解説し，次いで LIME の 枠組みをそ机らの動向と対比させて位置付けている。LIME 解説の中核をなすのは第 2 章および第 3 章であるが, 第 2 章では LIME で採用した 11 項目の影響領域それぞれについて詳細な解説が，第 3 章では統合化に関する解説がな されている。最後の第 4 章をま之めに当てているが，今後の課題の項を設けて LIME に内包された多数の課題が箇 条書きの形でリストアップされて抢り, LIME 理解の一助之もなっている。

LIME の被害算定型影響評価手法としての手順は，11 の影響領域（ミッドポイント）を 16 の被害カテゴリ（エン ドポイント) で被害評価した後，4つの保護対象（人間の健康・社会資産・生物多様性・一次生産）への影響として 集約し, 最後に統計学的手法を用いて単一指標化（統合化）する構造となっている。LCIAにおける統合化は最終的 には人間の価値観に依拠せざるを得ない分野であるため, 保護対象への影響評価までの自然科学的評価と社会科学的 評価による統合化とを峻別するとともに，各評価手順の透明性の確保に努めている。

本書に基づいて LIME 開発の特長と成果を大胆にまとめると，大きく次の 2 点をあげることができる。1つは環 境倫理学の成果を導入して 4 つの保護対象を設定し, 環境側面を社会的被害量の形に翻訳したことである。これは, 単に環境側面の単一指標化という環境経済学等からの期待に応えるだけでなく, 地域開発評価に用いられる環境乃セ スメント分野への応用や，さらに社会・環境側面を総合的に捉える CSR（企業の社会的責任）の定量化への応用に 道を開く試みとも位置付けら机る。

いま 1 つの特長は, これまで外国からの直輸入の色彩が強かった影響領域（ミッドポイント）において，あくまで 日本の環境条件や環境思想を反映させて領域項目を選定し，定量化手法を構築・提示したことである。特に資源や土 地, 自然など社会の共有資産に関わる影響をロジックとして積み上げた意義は大きく，またローカル，リージョナル な影響領域についての日本の地理的条件等の導入は被害のリアリティを追求する上で有効であったといえる。なお LIME 独自の影響領域として「廃衰物」が採用されているが，これはインベントリにおける中間計量物としての廃棄 物ではなく, 埋立処分という自然 (陸地・海面) 改变行為の影響を指す領域名称である。本書で紹介された影響領域 は定量化できた 11 項目にとどまっているが，LIME の外部性評価という目的からして，影響領域の網羅性のさらな る追及が期待される。

本書はその内容の多面性から，単なる LIME 理解の参考書としてだけでなく，LCIA の総合理解や各影響領域の詳 細理解，あるいは広義の社会資産への被害・便益評価手法理解など様々な読み方が可能である。是非とも一読をお奨 めする。

書 名：ライフサイクル環境影響評価手法

ISBN $4-914953-96$-X B 5 判 408 頁 定価 $¥ 9,450$ 円十税 2005 年発行

編 著: 伊坪徳宏・稲葉 敦

発行所：(社) 産業環境管理協会 干 101-0044 東京都千代田区鍛治町 2-2-1 TEL 03-5209-7710 FAX 03-5209-7716 


\title{
【書評】
}

\section{『寺西俊了覽修情報発伝所 編： 環境共同体としての日中韓』}

\author{
(独)国立環境研究所 大 迫 政 浩
}

アジアの国々をフィールドとして研究を展開している研究者は多いが, これまでは過去の公 害問題に対する経験を活かしてアジアの国々で起こっている問題の解決に協力していこう, と いう国際支援の文脈からの意義付けであったように思う。しかし，中国等の経済活動から生じ る環境污染物質が日本にも飛び火する酸性雨の問題などのように, 「対岸の火事」として無関 心ではいられない広域的な環境問題が顕在化し, さらに世界一の人口をあつ中国の急激な経済 発展に伴う温暖化ガス排出量の増加など, グローバルスケールでの環境影響についても東アジ アのウェイトは急速に高まっている。特に私達の分野では, 中国等の旺盛な資源需要に起因し て, 国際資源循環に伴う廃棄物の越境移動の在り方が問われている。

本書は，以上のような問題の背景，問題認識の下に，上記の視点を網羅した形で，関係する 多くの執筆者の事例的な報告と今後に向けた課題がメッセージとして紹介されている。

書評者はアジアの環境問題についてこれまであまり多くの知識をむっていなかったが, 本書を通じて現場的な臨場 感をむって，またそれぞれの国の事情を対比し時間・距離感を意識しながら理解することができた。

第一章では, 「世界の中で影響力を増大させる日中韓」として, 本書が書かれた問題背影がオーバービューされて いる。将来は米国や $\mathrm{EU}$ を屯追い越す程の経済発展の裏で地球環境問題やそれぞれの国での重篤な環境破壊が生じて いること，日中韓が相互に環境破壊の因果関係で結ばれていることなどが述べられる。

第二章では,「既に環境共同体! ? 相互に環境破壊を輸出し合う日中韓」として, 酸性雨, 黄砂, 廃衰物輸出, 漂 着ごみ, 日本企業の中国進出, 中国産農薬野菜の問題に関して, 詳説されている。本廃棄物学会の寺園氏も日本加 の廃棄物輸出の問題について述べている。

第三章では,「日中韓の環境問題には大きな共通点があった」として, 温暖化ガス, 原子力発電所, ダム開発によ る自然破壊, 外来種による生態系破壊, モータリゼーション, ゴミ問題などが取り上げられ, 問題により経時的に多 少の差があるが, 共通の問題構造を有する様々な環境問題について, それぞれの国の状況を事例を含めて説明してい る。

第四章では,「各国が直面する深刻な環境問題」として, 第三章までの比較的広い視野からの問題把握とは違い, 三国内の特定の場所における環境問題や公害事件がトピックスとして取り上げられ，臨場感が伝わる生々しいレポー トになっている。日中韓の環境 NGO/NPO のネットワークを大切に育ててきたが故に得られる貴重な情報や体験等 に支えられたものであることが推察される。

第五章では,「未来に向けた取り組みが始まった」として, それぞれの国での環境問題解決に, 環境 NGO が重要 な役割を果たしつつある取り組みについて紹介し，環境 NGO のネットワークを通したセクター間，国間の連携，協 力による活動が，持続可能な社会づくりに大きく貢献する可能性を示唆している。

本書の夕イトル中の「環境共同体」という用語からは，環境問題を通した一種の「運命共同体」というょうな内容 を予想したが，一部に論じられてはいるものの，日中韓個別の国々での問題事例についてのレポートがより多い内容 となっている。しかし，同じ経済圏として関係が強く密接になるほど，様々な文脈での「共同体」としての繫がりが 近い将来生ま机てくるであろうし，産業セクターでは CDM/JI な゙゙の温暖化対策ビジネスなどあ新しい動きとして 注目されている。監修者である寺西氏は「アジア環境白書」の編集・刊行など, アジアの NGO レベルでの活動展開 とネットワークづくりに精力的に取り組んでおられ, 編者である「東アジア環境情報発伝所」はまさに環境 NGO と して様々な環境協力の活動を行っている。今後のアジアの環境問題への対処には, 様々なセクターのレベルでの多面 的で重層的な「環境協力のためのネットワークづくり」の推進が重要であるとの監修者のあとがきにあるメッセージ には，大いに共感させられた。

\section{書 名：環境共同体としての日中韓}

ISBN 4-08-720326-3 新書判 254 頁 定価 $¥ 700$ 円十税 2006 年発行

監 修: 寺西俊一

編 集: 東アジア環境情報発伝所

発行所：侏) 集英社 ₹ 101-8050 東京都千代田区一ツ橋 2-5-10 TEL 03-3230-6393 